\title{
Reduction of environmental and energy footprint of microalgal biodiesel production through material and energy integration
}

\section{Authors: Raja Chowdhury, Sridhar Viamajala,\& Robin Gerlach}

NOTICE: This is a postprintof an article that originally appeared in Bioresource Technology on March 2012. DOI: http://dx.doi.org/10.1016/j.biortech.2011.12.099.

Chowdhury R, Viamajala S, Gerlach R, "Reduction of environmental and energy footprint of microalgal biodiesel production through material and energy integration," Bioresource Technology, March 2012 108:102-111 


\title{
Reduction of environmental and energy footprint of microalgal biodiesel production through material and energy integration
}

\author{
Raja Chowdhury ${ }^{a}$, Sridhar Viamajala ${ }^{a}, *$, Robin Gerlach ${ }^{b}$ \\ a Department of Chemical and Environmental Engineering, The University of Toledo, Toledo, OH 43606, United States \\ b Department of Chemical and Biological Engineering, Center for Biofilm Engineering, Montana State University, Bozeman, MT 59717, United \\ States
}

\begin{abstract}
The life cycle impacts were assessed for an integrated microalgal biodiesel production system that facil-itates energy- and nutrient- recovery through anaerobic digestion, and utilizes glycerol generated within the facility for additional heterotrophic biodiesel production. Results show that when external fossil energy inputs are lowered through process integration, the energy demand, global warming potential (GWP), and process water demand decrease significantly and become less sensitive to algal lipid content. When substitution allocation is used to assign additional credit for avoidance of fossil energy use (through utilization of recycled nutrients and biogas), GWP and water demand can, in fact, increase with increase in lipid content. Relative to stand-alone algal biofuel facilities, energy demand can be lowered by 3-14 GJ per ton of biodiesel through process integration. GWP of biodiesel from the integrated system can be lowered by up to $71 \%$ compared to petroleum fuel. Evaporative water loss was the primary water demand driver.
\end{abstract}

\section{Introduction}

Concerns over rapidly depleting fossil energy sources and esca-lating greenhouse gas emissions have resulted in an increased inter-est in alternative energy sources. Biofuels are a renewable alternative to fossil fuels that are compatible with existing automo-bile- and fuel-infrastructure. However, first-generation biofuels such as ethanol from corn and biodiesel from oil seeds, are unlikely to replace a significant fraction of the US petroleum demand without adversely affecting food production due to the low yields (per unit land area) of feedstocks from traditional agriculture (Chisti, 2007). In addition, corn and oil-seed crops require significant resources of fertile land, fertilizer, pesticides, and irrigation water. The potential for increase in agricultural run-off from extensive cultivation of these dedicated energy crops also poses significant environmental concerns (Donner and Kucharik, 2008). Overall, net greenhouse gas (GHG) emissions, energy demand and water demand are not favorable for first-generation biofuels (Clarens et al., 2010).

Microalgae-derived biodiesel is a promising renewable fuel (Yazdani and Gonzalez, 2007) and studies suggest that oil productiv-ities (per unit area) from microalgae can be nearly 8-20 times higher than those of plant oils (Chisti, 2007). However, algal fuel production involves more energy intensive processes for cultivation, harvesting and lipid recovery than conventional agriculture. Thus, overall energy and environmental impacts of algal biodiesel can only be determined through detailed life-cycle analyses of the fuel produc-tion processes. In addition, such analyses can also assist the develop-ment of more sustainable production options through identification of process steps that result in severe environmental effects.

Several recent LCA studies have reported on environmental im-pacts of algal biodiesel production relative to fossil- or other alter-native-fuels (Batan et al., 2010; Clarens et al., 2010; Collet et al., 2010; Lardon et al., 2009; Sander and Murthy, 2010; Yang et al., 2011). The life-cycle global warming potential (GWP) of algal bio-diesel has been assessed to be lower than that of petroleum diesel as well as of biodiesel derived from soy or canola (Batan et al., 2010; Lardon et al., 2009). However, studies also estimated that the GWP of algal biodiesel was likely higher than that of biodiesel from palm- or rapeseed oil (Lardon et al., 2009). One of the poten-tial methods of reducing GWP associated with algal biodiesel is through generation of multiple byproducts in the biorefinery. In such systems, the life-cycle burden can be distributed among all the products (commonly calculated through allocation procedures) thus lowering the life-cycle burden of biodiesel alone. Batan et al.(2010) used this approach to distribute overall process GWP to the two products in their system - biodiesel and algae residue. Sander and Murthy (2010) allocated their GWP to biodiesel and ethanol (derived from algal carbohydrates).

A more direct approach for lowering life-cycle energy demand is through minimization of external fossil energy inputs or fossil-derived raw materials. External energy needs could be reduced if the energy contained in the non-lipid portion of algal biomass (not utilized for biodiesel production) was recovered and utilized 
within the biorefinery. Also, since the nutrients remain largely associated with the non-lipid portion of algal cells, recycling of nutrients from post-extraction residues would result in less external fertilizer use - the major fossil-derived material input into algal biorefineries (Clarens et al., 2010). One method to accomplish both goals of nutrient and energy recovery from algae residues is through anaerobic digestion (Collet et al., 2010). Biogas from anaerobic digestion could be combusted to supplement heat needs for the algal biorefinery such as for algae drying - a step commonly believed to be most energy intensive in the algal biofuels process (Baliga and Powers, 2010; Lardon et al., 2009; Sander and Murthy, 2010). In addition, the digested slurry which is rich in bioavailable nutrients could be used for algae growth. Besides contributing to reduction of biofuel GWP, recycling of nutrients is also essential for resource conservation. Previous studies estimated that if algal biodiesel were to replace a major fraction of the US fuel needs, nutrient use for algae cultivation would result in a several-fold increase in nutrient demand compared to current nutrient production (Batan et al., 2010). Phosphorus is especially critical, since even at the current rates of agricultural use, world mineral phosphorus reserves are expected to be depleted in 50-100 years (Cordell et al., 2009).

Glycerol generated during conversion of lipids to biodiesel is another co-product that is likely to be produced in large quantities in algal biorefineries. Even with current levels of biodiesel production from oil seeds, the commercial worth of the crude glycerol has diminished to a large extent and glycerol is now even considered to be "waste" (Yazdani and Gonzalez, 2007). It is unlikely that crude glycerol from algal biorefineries would have significant marketvalue; however, glycerol could be used within the algal biorefinery to generate additional biodiesel through heterotrophic fermentation (Yokochi et al., 1998). Through this approach, energy costs associated with waste disposal or off-site transportation could be reduced.

Overall, an integrated approach of resource management and nutrient utilization is likely to result in more sustainable production of algal biodiesel. It is important to note that previous LCA analyses on algal biofuel have focused on stand-alone production systems with energy inputs coming from external sources and, in most cases, co-products were removed from the system boundary. Further, each of these studies assumes a different cellular lipid content making it difficult to relate the relative importance of lipid productivity on the energy demand and GWP of algal biofuels. In this study, estimates have been made for the energy demand, GWP, and water demand associated with production of the algal biodiesel in an integrated system that incorporates (1) recovery of energy and nutrients from algal residues through anaerobic digestion and (2) on-site glycerol utilization for production of additional biodiesel and docosahexaenoic acid - a high-value nutritional supplement. In some recent studies that have considered integrated algae processes (Brentner et al., 2011; Clarens et al., 2011), the emphasis has been on comparing life-cycle impacts of alternate unit operations for the same process (e.g. flocculation versus centrifugation for solid-liquid separation). In contrast, we sought to establish relationships of LCA parameters (energy demand, GWP, and water demand) on process-relevant variables - lipid content and biomass productivity. Thus, this LCA study focuses on minimizing the environmental impact associated with algal biodiesel by maximizing resource utilization within an integrated system. Overall, this study seeks to understand the effects of algal lipid content on life-cycle GWP as well as energy and water-demand.

\section{Methodology}

This study uses a process-based life-cycle analysis approach in which the first step is to develop the goal and scope of the study and is primarily accomplished through development of an appropriate system boundary. Fig. 1 shows the system boundary of the present study. A detailed description of the processes included in the system boundary is given in the "Supporting information" section. Algae-based biodiesel production is still at the research and development stage and therefore, actual productionscale processes are non-existent. However, it is reasonable to expect that algal biofuel production, when commercially implemented, will resemble existing industrial processes. Hence, some process steps within the system boundary (e.g. dewatering and drying of algae) are modeled using data for other similar processes being currently practiced. Some of the water consumption data were taken from the EIOLCA database (www.eiolca.net) (discussed in Sections 2.1.1 and 2.1.5). Since construction and maintenance related activities have only minor effects on the overall environmental impacts (Ruether et al., 2005), they were not included in the scope of this study.

\subsection{Life-cycle inventory}

Life-cycle data for most of the processes were collected from peer-reviewed publications and reports. Inventory data used for this study along with the sources are given in Table 1.

\subsubsection{Fertilizer (nutrient) production}

NPK fertilizer was assumed to be produced through the mixedacid route followed by granulation through a pipe reactor. Data on energy consumption and raw material requirements (ammonia, phosphoric acid, sulfuric acid, nitric acid, and potash) for fertilizer production by this method were collected from the European Fertilizer Manufacturing Association (EFMA) (EFMA, 2000). Life-cycle data for production of these raw chemicals used in fertilizer production were taken from multiple sources and are listed in Table 1. Water consumption for production of fertilizer was collected from EIOLCA (www.eiolca.net, accessed on September 14, 2010) using the 2002 US national purchaser price model and using the prices of ammonium nitrate and superphosphate (http://www.ers.usda.gov/Data/FertilizerUse, accessed on September 14, 2010). Sources of data for other elements of the algal growth system (described in detail in Supporting information) are also given in detail in Table 1. Nutrient requirements were calculated using the stoichiometric formula $\mathrm{C}_{106} \mathrm{H}_{263} \mathrm{O}_{110} \mathrm{~N}_{16} \mathrm{P}$ for the non-lipid portion of algal cells and from estimates of algal biomass productivities (Note: A lipid producing algal cell was assumed to consist of triacylglycerides along with other cellular components/biopolymers with a general stoichiometry of $\mathrm{C}_{106} \mathrm{H}_{263} \mathrm{O}_{110} \mathrm{~N}_{16} \mathrm{P}$ (Redfield, 1958)). Further, it was assumed that $65 \%$ of the required nutrients were obtained as a recycle stream from anaerobic digestion. $\mathrm{N}$ requirements for lipid producing algae may be calculated as

$N=M(1-F) \frac{16\left(M W_{N}\right)}{\left(M W_{C}\right)}$

where $M=$ biomass produced, $F=$ cellular lipid content (as $\mathrm{w} / \mathrm{w}$ fraction of lipid relative to total dry cell mass), $M W_{N}=$ molecular weight of nitrogen and $M W_{C}=$ molecular weight of the non-lipid portion of algal cell (calculated from $\mathrm{C}_{106} \mathrm{H}_{263} \mathrm{O}_{110} \mathrm{~N}_{16} \mathrm{P}$ ). Eq. (1) has been written assuming that the lipid fraction of algal biomass is $\mathrm{N}$ and $\mathrm{P}$ free. $\mathrm{P}$ requirements were determined through analogous calculations.

\subsubsection{Fermentation}

It is possible to utilize glycerol, generated as a co-product during conversion of algal triglycerides to biodiesel, for further production of lipids through heterotrophic fermentation. Fermentative biodiesel production was modeled using literature data for the microalgae Schizochytrium limacinum. Biomass yields of 0.39 g-biomass g-glycerol ${ }^{-1}$ (Yokochi et al., 1998) and a total lipid content of $0.5(\mathrm{w} / \mathrm{w}$, dry basis) with $60 \%$ palmitic acid and 


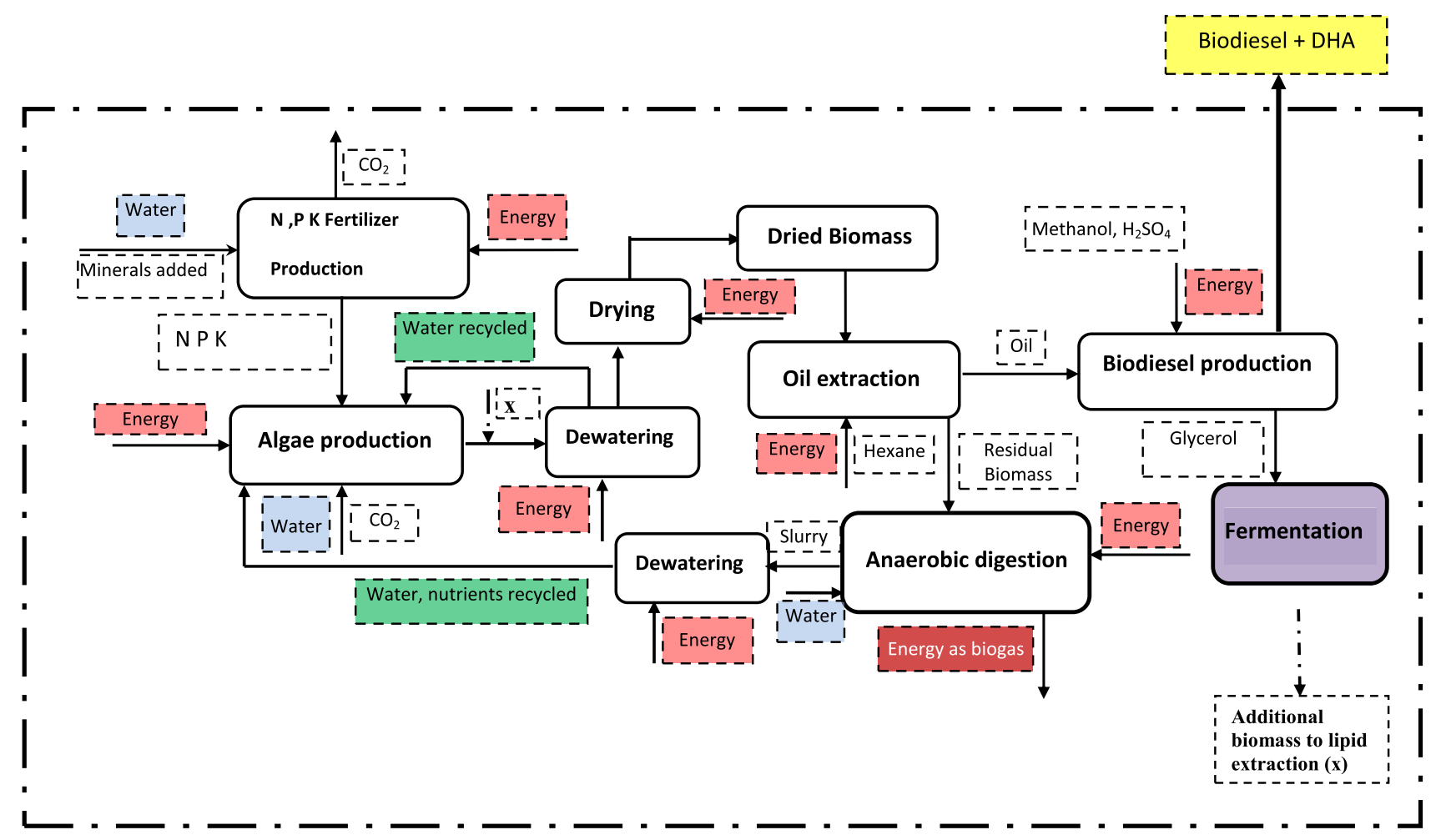

Fig. 1. System boundary of the biodiesel production process.

Table 1

Sources of life cycle data used in the present study.

\begin{tabular}{|c|c|c|c|}
\hline $\begin{array}{l}\text { Products/ } \\
\text { processes }\end{array}$ & $\begin{array}{l}\text { Ingredients/ } \\
\text { requirement }\end{array}$ & Sources & Other comments \\
\hline N P K fertilizer & $\begin{array}{l}\mathrm{H}_{2} \mathrm{SO}_{4}, \mathrm{H}_{3} \mathrm{PO}_{4}, \mathrm{NH}_{3}, \mathrm{~K}_{2} \mathrm{O} \\
\mathrm{HNO}_{3} \text {, energy }\end{array}$ & EFMA (2000) & Water data were collected from www.eiolca.net \\
\hline $\mathrm{NH}_{4} \mathrm{NO}_{3}$ & $\mathrm{NH}_{3}, \mathrm{HNO}_{3}$, energy & EFMA $(2000 b)^{\dagger}$ & Amount of $\mathrm{NH}_{3}$ and $\mathrm{HNO}_{3}$ required were calculated from stoichiometry \\
\hline $\mathrm{H}_{2} \mathrm{SO}_{4}$ & & EFMA $(2000 a)^{\dagger}$ & \\
\hline $\mathrm{H}_{3} \mathrm{PO}_{4}$ & & EFMA $(2000 c)^{\dagger}$ & \\
\hline $\mathrm{NH}_{3}$ & & $\begin{array}{l}\text { Kongshaug and Jenssen } \\
(2003)^{\dagger}\end{array}$ & \\
\hline $\mathrm{K}_{2} \mathrm{O}$ & & $\begin{array}{l}\text { Kongshaug and Jenssen } \\
(2003)^{\dagger}\end{array}$ & \\
\hline $\mathrm{HNO}_{3}$ & $\mathrm{NH}_{3}$ & $\begin{array}{l}\text { Kongshaug and Jenssen } \\
(2003)^{\dagger}\end{array}$ & \\
\hline Energy & Coal and natural gas & $\begin{array}{l}\text { Spath et al. (1999) and } \\
\text { Spath and Mann }(2000)\end{array}$ & \\
\hline $\mathrm{CO}_{2}$ injection & & Lardon et al. (2009) & $\begin{array}{l}\mathrm{CO}_{2} \text { requirement was calculated by taking into account the carbon content of algal cells } \\
\left(\mathrm{C}_{106} \mathrm{H}_{263} \mathrm{O}_{110} \mathrm{~N}_{16} \mathrm{P}\right) \text { and oil (assumed to be present as triolein) }\end{array}$ \\
\hline Dewatering & Energy & USEPA (1985) & $\begin{array}{l}\text { Dewatering energy was calculated using Eq given in the "Recessed plate filter press } \\
\text { dewatering" section of (USEPA 1985) }\end{array}$ \\
\hline Drying & Energy & $\begin{array}{l}\text { Calculated according to } \\
\text { Eq. S1 }\end{array}$ & \\
\hline Extraction & Hexane, energy as heat & Batan et al. (2010) & \\
\hline Transestification & $\begin{array}{l}\text { Methanol, acid, energy } \\
\text { as heat }\end{array}$ & Lardon et al. (2009) & \\
\hline $\begin{array}{l}\text { Anaerobic } \\
\text { digestion }\end{array}$ & $\begin{array}{l}\text { Electric energy, residual } \\
\text { biomass, water }\end{array}$ & Murray et al. (2008) & Biogas production and related calculations are in Supporting information \\
\hline Fermentation & $\begin{array}{l}\text { Glycerol, energy for } \\
\text { agitation, fertilizer }\end{array}$ & $\begin{array}{l}\text { Akiyama et al. (2003) })^{\dagger} \text { and } \\
\text { Yokochi et al. (1998) }\end{array}$ & \\
\hline
\end{tabular}

${ }^{\dagger}$ References in Supporting Information.

$30 \%$ docosahexaenoic acid were used. Biomass residues (remaining after oil extraction) of $S$. limacinum were fed to the anaerobic digester along with residues of phototrophically grown algae.

\subsubsection{Anaerobic digestion}

Biomass residues remaining after lipid extraction were modeled as being processed through anaerobic digestion. Influent solid concentration to the anaerobic digester was assumed to be
$70 \mathrm{~g} \mathrm{~L}^{-1}$ (Fischer and Porter, 1984). Chemical oxygen demand (COD) of the biomass residues was estimated as $1.23 \mathrm{~g}$-COD g-solids ${ }^{-1}$ and COD reduction was assumed to be $80 \%$ - a value typical of high rate anaerobic digesters (Kim et al., 2002) With this digestibility assumption, it was estimated that $65 \%$ of the incoming biomass-associated nutrients would solubilized and thereby become bioavailable. A methane yield of $0.28 \mathrm{~L}^{-\mathrm{CH}_{4}}$ g-digestedsolids $^{-1}$ was assumed based on literature values (Briand and 
Morand, 1997; Bruhn et al., 2011; De Schamphelaire and Verstraete, 2009). Electricity consumption data for operating the anaerobic digester was obtained from Murray et al. (2008). Biogas produced during digestion was used to generate heat for use within the biorefinery. Effluent from the digester was dewatered through a recessed plate filter press and the liquid portion was assumed to have the bioavailable nutrients to be recycled for phototrophic algal growth.

\subsubsection{Lipid extraction and transesterification}

Lipid extraction from dry biomass was assumed to be carried out using hexane and the energy requirement for this process was obtained from Batan et al. (2010). Consistent with previous studies, energy and emission data for hexane were assumed insignificant and ignored (Batan et al., 2010; Lardon et al., 2009). After extraction, lipid was assumed to be transesterified to biodiesel by reacting with methanol in the presence of an acid catalyst. The pertinent data for transesterification were collected from Lardon et al. (2009). During the transesterification process, 0.1 ton of glycerol is generated per ton of biodiesel produced (Van Gerpen et al., 2004).

\subsubsection{Emissions from electricity consumption}

Electricity was assumed to be derived from both coal (70\%) and natural gas (30\%) which is in accordance with the average US energy mix (Batan et al., 2010). Emission data for gas-based electricity generation were collected from the literature (Spath and Mann, 2000) using modified emission factors (Chowdhury et al., 2010). Water demand for electricity production was obtained from EIOLCA (http://www.eiolca.net, accessed on September 14, 2010). The 2002 US national purchaser price model was used. Cost of electricity was assumed to be 4.88 cents $\mathrm{kWh}^{-1}$. (www.eia.doe.gov/cneaf/ electricity/epa/epaxlfile7_4.pdf, accessed on November 19, 2010).

\subsection{Life-cycle impact categories}

The collected life-cycle data were divided into the following impact categories (i) GWP, (ii) energy demand and (iii) water demand.

\subsubsection{Energy demand}

The heat and electric energy needs for the processes within the system boundary were summed separately. Net heat energy needed was calculated by subtracting the energy of biogas (38.8 $\mathrm{MJ} \mathrm{m}^{-3}$ of methane) (Murray et al., 2008) generated during anaerobic digestion from the total heat input. Net energy demand of the processes was calculated by adding the net heat and electricity requirements. Net energy requirements for the biorefinery were assumed to be supplied from electricity.

\subsubsection{GWP}

In this study, GWP has been reported in terms of $\mathrm{kg}-\mathrm{CO}_{2}$ equivalent using conversion factors for greenhouse gases developed by the Intergovernmental Panel on Climate Change (IPCC) (Chowdhury et al., 2010). Greenhouse gas emissions from all the processes were aggregated. In accordance with IPCC guidelines, $\mathrm{CO}_{2}$ released due to combustion of biogas was assumed to be carbon neutral (Murray et al., 2008).

\subsubsection{Water demand}

Water demand for biofuels from lignocellulosic biomass has been estimated in several previous studies (Baliga and Powers, 2010; Clarens et al., 2010; Dominguez-Faus et al., 2009; Harto et al., 2010; Yang et al., 2011) which reported evaporation to be the major contributor to water demand. Since evaporation is a surface phenomenon and depends on the total surface area covered by algal ponds, water demand for a fixed product output system (e.g.
1 ton-biodiesel day ${ }^{-1}$ ) will vary with areal productivity, in addition to the rate of evaporation (usually reported as $\mathrm{cm} \mathrm{day}^{-1}$ ). In the present study, evaporative water loss was calculated assuming areal productivities of 10 and $25 \mathrm{~g} \mathrm{~m}^{-2}$ day $^{-1}$ (low and high) (Mata et al., 2010) and a pond depth of $30 \mathrm{~cm}$. For the lowest evaporation losses, an areal productivity of $25 \mathrm{~g} \mathrm{~m}^{-2}$ day $^{-1}$ and an annual average evaporation rate of $50 \mathrm{~cm} \mathrm{yr}^{-1}$ was used (Redmond, 2007). The highest evaporation loss was modeled using an areal productivity of $10 \mathrm{~g} \mathrm{~m}^{-2}$ day $^{-1}$ and an annual average evaporation loss of $94 \mathrm{~cm} \mathrm{yr}^{-1}$ (Redmond, 2007). Water requirement for photosynthesis was assumed to be $0.75 \mathrm{~L} \mathrm{~kg}^{-1}$ of algal biomass produced (Wijffels and Barbosa, 2010). The calculation procedure for water demand is presented in the Supporting information. Water demand from evaporative water losses was reported as $\mathrm{m}^{3}$ ton-biodiesel ${ }^{-1} \mathrm{yr}^{-1}$.

\subsection{Distribution of life-cycle impacts among biorefinery products}

The present study produces two products that leave the system boundary - biodiesel and docosahexaenoic acid (DHA). Produced DHA is only a small fraction of the biodiesel (0.05\%) and no impact was allocated to it. Also, undigested solids from the anaerobic digester were assumed to be inert and no impacts were allocated (discussed in Section 3.2.2 below). In addition, a substitution allocation procedure was applied to biogas energy and recycled nutrients. No substitution was applied to crude glycerol generated from biodiesel production. According to the International Standard Organization (ISO), allocation applied as substitution for displaced products is a preferred allocation method (Kaufman et al., 2010). In this allocation method, credit is allocated for substituting a conventional product with an alternative product generated by the novel process proposed. To evaluate this credit, the values of energy demand, GWP and water demand of the conventional products are deducted from the corresponding values calculated for the whole system.

\subsection{Scenarios analyzed}

After developing the life-cycle inventory and finalizing the lifecycle impact categories, scenarios with varying biomass lipidcontents $(0.4,0.5,0.6$ and $0.7(\mathrm{w} / \mathrm{w}$, fraction of lipid relative to total dry cell mass)) were analyzed. Nutrient inputs for algal growth are assumed to be just sufficient for biomass production based on cell stoichiometry and $65 \%$ of these nutrients were obtained as a recycle stream from anaerobic digestion. For each assumed lipid-content, the following scenarios were simulated:

(i) A base case scenario for a stand-alone biodiesel facility that did not integrate/reuse energy and nutrients obtained from anaerobic digestion. This scenario was simulated to depict a "worst-case" where all the energy and nutrient needs would be met through external inputs.

(ii) Two process integration scenarios

(a) A without-allocation scenario where energy (biogas) and nutrients from anaerobic digestion and water from dewatering are integrated back into the process. Therefore, the net external energy, nutrient, and water input are minimized and lowered the process energy demand, GWP and water demand.

(b) A with-allocation scenario where, in addition to integrating energy, nutrients and water back into the process, substitution credit was allocated to the co-products that were generated through anaerobic digestion. Natural gas based electricity and NPK fertilizer were assumed as conventional products which are substituted by methane and recycled nutrients recovered from the anaerobic 
digestion. Consistent with the substitution allocation procedure, energy demand, GWP and water demand of natural gas based electricity and $\mathrm{N}, \mathrm{P}$ fertilizer were deducted from the corresponding values of these parameters for the whole system.

\section{Results and discussion}

\subsection{Energy demand}

\subsubsection{Energy demand reduction through process integration}

The energy demand for the base-case, "with-allocation" and "without-allocation" scenarios are shown in Fig. 2a. For the basecase, the calculated energy demand was the highest since all energy inputs for the process were derived from external sources. Also, in the base case, the algal biomass was processed for biodiesel only and the biomass residue was assumed to be a waste product. In the base case, an increase in lipid content from 0.4 to $0.7(\mathrm{w} / \mathrm{w}$, fraction of lipid relative to total dry cell mass) decreased the energy demand significantly (by $10 \mathrm{GJ}$ ton-biodiesel ${ }^{-1}$ for the system modeled here) since production of 1 ton biodiesel from lipid-rich algae requires less biomass and thereby less nutrient and energy inputs. When process integration (through anaerobic digestion and fermentation) is included in the system, the overall energy demand decreased and energy demand for the with-allocation scenario was even lower than for the without-allocation case (Fig. 2a). It is interesting to note that in simulated process integration scenarios, the energy demand is much less sensitive to biomass lipid content. In the integrated system (both without- and with-allocation scenarios), residual biomass was processed for energy production and nutrient recovery. As a result, for low lipid containing algae, more biomass was left for biogas production and nutrient recovery compared to high lipid containing algae (on a per ton biodiesel basis). When the recovered energy and nutrients are recycled back into the system through such process integration, less external energy is needed and thus energy demand is lowered. In the with-allocation scenario, energy demand was further decreased by incorporating energy credit from nutrient recycling and biogas use (Fig. 2a). In fact, for the energy consumption values used in this study (primarily those associated with
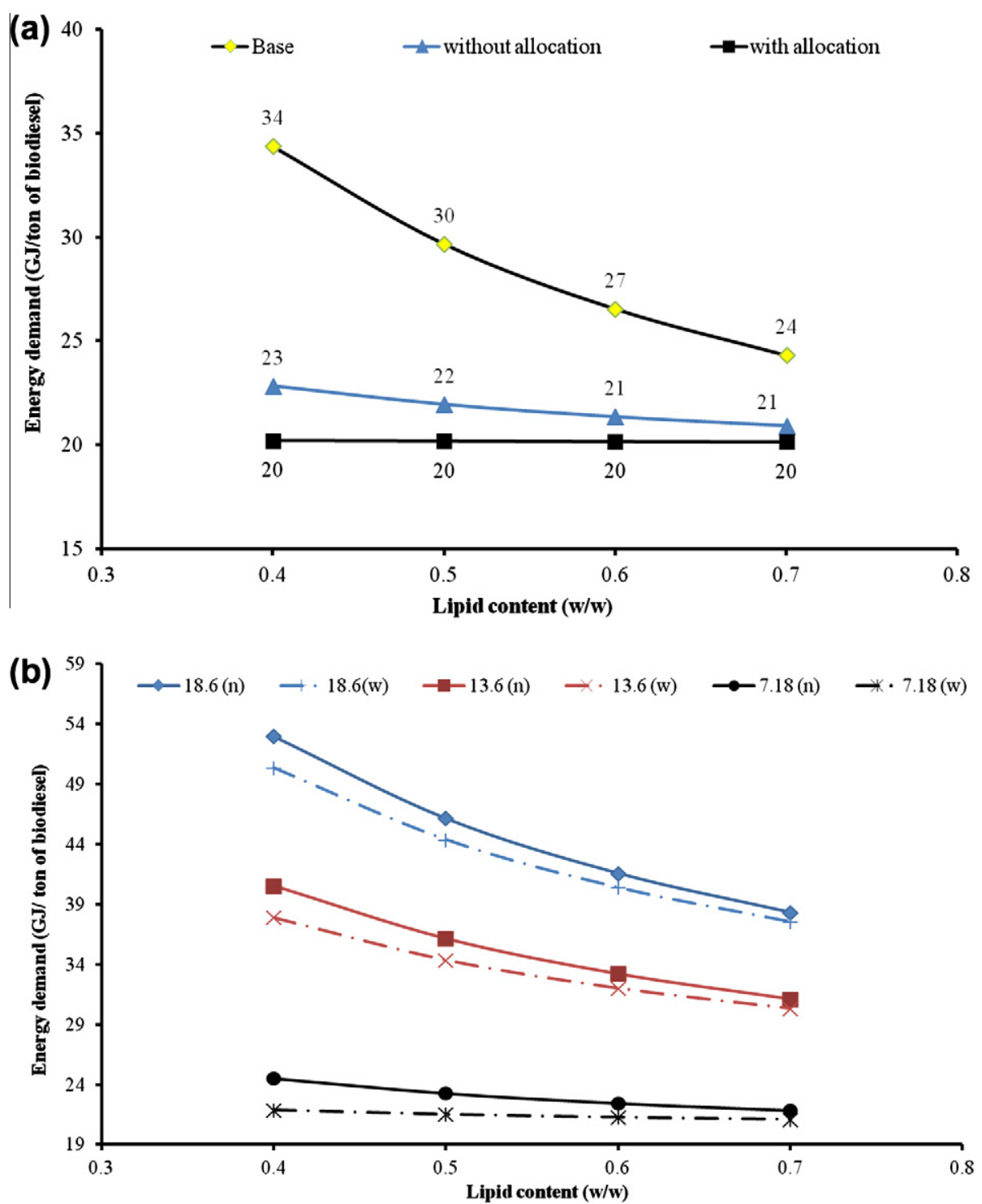

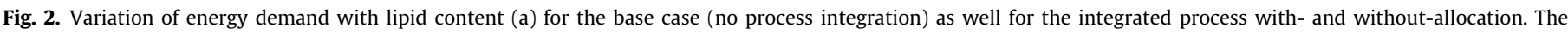

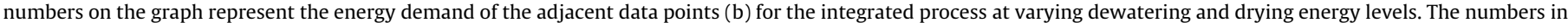

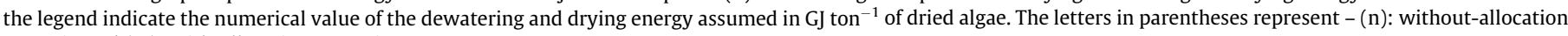
scenario and $(w)$ : with-allocation scenario. 
dewatering and drying), the energy demand is virtually unchanged for all the lipid content conditions for the integrated process with allocation.

Although energy demand (per ton biodiesel) remained nearly unchanged for the case shown in Fig. 2a, the net energy demand is, in fact, a function of the total energy used in the process. If energy needs (primarily due to dewatering and drying) are higher than those assumed in the simulations performed here, energy demand in fact decreases with increasing biomass lipid content (Fig. 2b). However, this trend (i.e. slope) decreases with decreasing dewatering and drying energy needs. The energy demand becomes almost constant when energy needs for dewatering and drying are low (below $7.18 \mathrm{GJ}$ ). Thus, it is possible to conceive process scenarios where the environmental footprint for biofuel is effectively not driven by biomass lipid content. When open pond systems and/or wastewater are used for algal cultivation, high lipid productivities may be difficult to achieve on a consistent basis. In such cases, process improvements to achieve more energy efficient methods for dewatering and drying (or wet extraction) will make the environmental impact of the process less sensitive to lipid content.

Waste heat from power plant flue gases could also be used for algae drying as recently suggested (Pokoo-Aikins et al., 2010; Xu et al., 2011). In coal fired power plants, around $8 \%$ of the input energy is lost with flue gas. If one assumes a flue gas temperature of $150{ }^{\circ} \mathrm{C}$ and flue gas specific heat of $1.2 \mathrm{~kJ} \mathrm{~K}^{-1} \mathrm{~kg}^{-1}$ (Coskun et al., 2009), 10\% of the flue gas heat energy can be used for drying algal biomass (assuming flue gas energy to be zero at $-273^{\circ} \mathrm{C}$ ). In a $1000 \mathrm{MW}$ coal fired power plant, heat lost with the flue gas can be as high as $10464 \mathrm{GJ} \mathrm{day}^{-1}$ (Sarunac et al., 2007). Therefore, if the algal biorefinery was situated close to a $1000 \mathrm{MW}$ coal-fired power plant, waste heat from the flue gas can dry enough algal biomass to produce 64-111 ton-biodiesel day ${ }^{-1}$, depending upon biomass lipid content. In addition, $\mathrm{CO}_{2}$ available in the flue gas could also be utilized for algal growth and thus reduce the GWP of coal fired power plants.

\subsubsection{Energy demand components}

The various sources of energy demand in the algal biofuel process are (i) nutrient production, (ii) algal growth (iii) dewatering and drying and (iv) other miscellaneous processes. In the simulations for the integrated process (with- and without-allocation), a part of the energy demand was satisfied by biogas produced from the anaerobic digestion. Depending on the scenario, 10\% (0.7 lipid content ( $\mathrm{w} / \mathrm{w}$, fraction of lipid relative to total dry cell mass) and without-allocation) to $30 \%$ ( 0.4 lipid content $(w / w$, fraction of lipid relative to total dry cell mass) and with-allocation) of the total energy demand could be met by the biogas (Fig. S1, Supporting information).

Dewatering and drying was found to be the major energy consumer as 9-16 GJ of energy was needed for these steps per ton of biodiesel produced. Lardon et al. (2009), Baliga and Powers (2010), and Sander and Murthy (2010) also found that dewatering and drying was the most energy-intensive step in algal biodiesel production. If nutrient recycling and anaerobic digestion were not taken into consideration (base case), energy demand could be much higher (by as much as $3-14 \mathrm{GJ} \mathrm{ton}^{-1}$ biodiesel produced) (Fig. 2a). Other studies that did not consider the nutrient and energy integration (Batan et al., 2010; Lardon et al., 2009) have reported higher energy demand than the estimates presented in this study. Also, the net energy demand calculated in this study (20-23 GJ ton ${ }^{-1}$ biodiesel at a lipid content (w/w) of 0.4 ) was comparable to the estimates by Xu et al. (2011) (18-20 GJ) but higher compared to net energy demand calculated by Stephenson et al. (2010) ( 5 GJ) likely due to more conservative estimates of energy consumption used in this study. Energy recovery from anaerobic digestion estimated by Stephenson et al. (2010) was $\sim 6$ GJ higher than the value assumed in this study.

Readers may observe variability in LCA results reported in previous studies and these discrepancies are largely due to variable LCA data (e.g. energy demand for various processes, nutrients used, allocation method, lipid content, etc.) used for calculation and especially the dewatering energy (Table 2 ). For example, previous LCA studies employing centrifugation for algae dewatering (Batan et al., 2010; Lardon et al., 2009; Xu et al., 2011) have reported highly variable energy requirements for this step (26.5$400 \mathrm{kWh} \mathrm{ton}^{-1}$ of dry algae). However, filtration-based dewatering techniques are expected to use less energy compared to centrifugation and are likely to have less variability (Uduman et al., 2010). Therefore, in this study, recessed plate filter press-based dewatering was used. The recessed plate filter can concentrate the slurry to $40 \%$ solid content and thus reduce the drying energy required (USEPA, 1985).

\subsubsection{Net energy ratio}

The Net Energy Ratio (NER) (total fossil energy required/energy produced), an indicator of life-cycle energy efficiency of a manufactured product, was also calculated in this work. Integrating anaerobic digestion with algal biodiesel production can decrease the NER from a base-case value of $0.79-0.58$ (50\% lipid content and without allocation). Integrating waste heat from the flue gas can

Table 2

Material and energy requirements for the production of 1 ton of dry algae with an oil content of 0.4 .

\begin{tabular}{|c|c|c|c|}
\hline Materials/energy & Present study & Other data from literature & References \\
\hline \multicolumn{4}{|c|}{ Growth and harvesting stage } \\
\hline Nitrogen $(\mathrm{kg})$ & 38 & $\begin{array}{l}10.9(\mathrm{~L}) 46(\mathrm{H})^{\mathrm{a}} ; 147^{\mathrm{b}} \\
174^{\mathrm{c}}, 63.7^{\mathrm{d}}, 132^{\mathrm{e}}, 23.6^{\mathrm{f}}\end{array}$ & 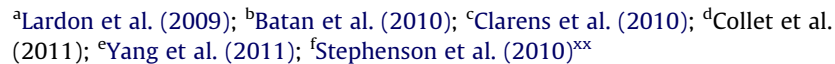 \\
\hline Phosphorus (kg) & 5.3 & $\begin{array}{l}2.4(\mathrm{~L}) \text { and } 9.9(\mathrm{H})^{\mathrm{a}} ; 20^{\mathrm{b}} \\
25.7^{\mathrm{c}}, 9.97^{\mathrm{d}}, 93^{\mathrm{e}}\end{array}$ & $\begin{array}{l}\text { a Lardon et al. (2009); }{ }^{b} \text { Batan et al. (2010); }{ }^{\mathrm{c}} \text { Clarens et al. (2010); }{ }^{\mathrm{d}} \text { Collet et al. } \\
\text { (2011); ' Yang et al. (2011) }\end{array}$ \\
\hline $\begin{array}{l}\text { Dewatering energy } \\
\quad(\mathrm{kWh}) / \text { dry ton algae }\end{array}$ & $\begin{array}{l}13-31 \text {, (recessed plate } \\
\text { filter press dewatering) }\end{array}$ & $400^{\mathrm{a}}, 338^{\mathrm{b}, *}, 18.7^{\mathrm{c}}, 42^{\mathrm{d}}$ & 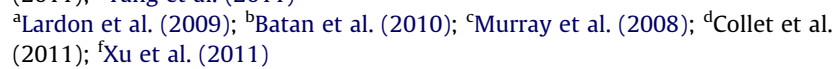 \\
\hline $\begin{array}{l}\text { Drying energy (GJ/dry } \\
\quad \text { ton algae processed) }\end{array}$ & 6.33 & $13.8^{\mathrm{a}}, 4.314^{\mathrm{f}}$ & ${ }^{\mathrm{a}}$ Lardon et al. (2009); ${ }^{\mathrm{X}} \mathrm{Xu}$ et al. $(2011)^{\mathrm{t}}$ \\
\hline $\begin{array}{l}\mathrm{CO}_{2} \text { purging }(\mathrm{kWh} / \text { ton } \\
\text { algae produced) }\end{array}$ & $42.5^{* *}$ & $16^{\mathrm{a}}, 28.9^{\mathrm{d}}$ & ${ }^{\mathrm{a} B a t a n}$ et al. (2010); ${ }^{\mathrm{d}}$ Collet et al. (2011) \\
\hline
\end{tabular}

a-f are given as indicators for reference in right most column

$\mathrm{L}$ and $\mathrm{H}$ stand for low and high nutrient demands, respectively.

* Includes energy for drying.

** Calculated from $22.2 \mathrm{Wh} \mathrm{kg}^{-1} \mathrm{CO}_{2}$ purged [source: Lardon et al. (2009)].

xx Assumed 40\% oil.

${ }^{\mathrm{t}}$ Except mechanical dewatering (60 kWh ton ${ }^{-1}$ dry algae). 

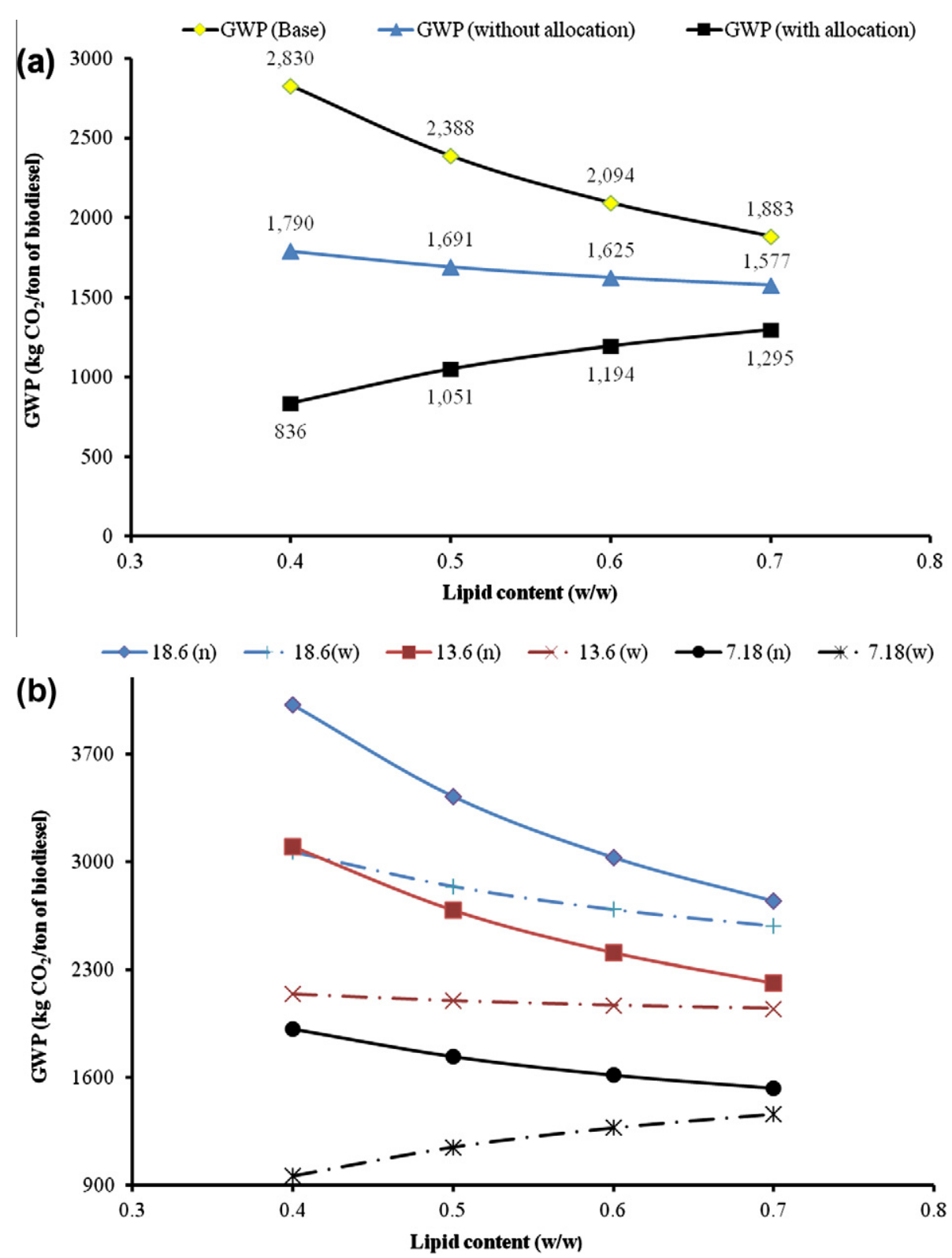

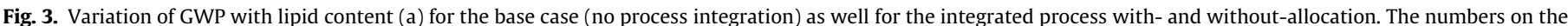

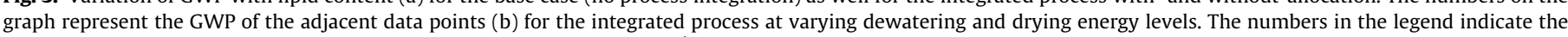

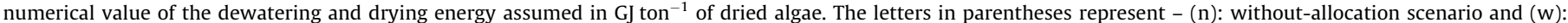
with-allocation scenario.

further reduce the NER to 0.41 (assuming that 50\% of drying energy was derived from flue gas). For comparison, Xu et al. (2011) reported a NER of $0.67-0.81$.

\subsection{Global warming potential (GWP)}

\subsubsection{GWP reduction through process integration}

The GWP generated from 1 ton of biodiesel production is shown in Fig. 3a. Similar to trends observed for the energy demand (Fig. 2a), GWP for the base case (no process integration) was the highest due to the relatively high fossil energy inputs in this scenario; however, GWP decreased substantially with increasing lipid content. When nutrient and energy integrations were accounted for, fossil energy and external nutrient inputs decreased and correspondingly, GWP was also lower compared to base case. For the without-allocation scenario, the GWP was less sensitive to lipid content for the same reasons described above for energy demand trends (Fig. 2a).
However, for the with-allocation scenario the increase in GWP with increase in lipid content was striking. In this scenario, biogas production and nutrient recovery is directly proportional to the biomass left after lipid extraction. For lower lipid containing algae, more biomass was left after lipid extraction compared to higher lipid containing algae. Hence, GWP credit for nutrient and biogas was greater for lower lipid containing algae compared to higher lipid containing algae. When, GWP generated through external energy and materials demand is not excessive, GWP credits from substitution can offset the GWP created by the biofuel process. In the simulation presented here, GWP showed an upward trend with increasing lipid content for the with-allocation scenario. It is important to correctly interpret the significance of this result. Higher lipid productivity through growth of high lipid-containing algae would normally imply greater economic value through sale of the biofuel. However, if monetary credit for GWP reduction becomes available in the future, the results from this study suggest 
that processes that rely on production of biodiesel from lower-lipid containing algae could also be economically competitive provided appropriate process integration strategies are applied. It is also important to note that GWP could still decrease with increasing lipid content when net fossil energy inputs into the system are high. In such cases, the GWP offset due to allocation credit is less significant than the GWP generated through greater fossil energy use. Increase in GWP with increase in lipid content was observed at or below a dewatering and drying energy (13.6 GJ) (Fig. 3b).

\subsubsection{GWP components}

In the present study, the GWP calculations accounted for algal growth to biodiesel production. GWP for biodiesel production did not include combustion of biodiesel. Further, the fatty acid portion of biodiesel was assumed to be derived from carbon captured during photosynthesis while the methyl part of the molecule was not carbon-neutral. Since algal biodiesel contains fatty acid methyl ester molecules with 8-20 carbon atoms (Schenk et al., 2008) and a molecular weight ranging from 157 to $324 \mathrm{~g} \mathrm{~mol}^{-1}$, one ton of biodiesel combustion will produce between 135 and $280 \mathrm{~kg}$ of $\mathrm{CO}_{2}$ that was not originally in the atmosphere prior to algae growth. These calculation procedures were used to estimate GWP produced by combustion of biodiesel.

Based on calculations in this study, GWP for algal biodiesel could range between 2830 and $836 \mathrm{~kg}-\mathrm{CO}_{2}$ ton-biodiesel ${ }^{-1}$ (except the $\mathrm{CO}_{2}$ generated from combustion). In comparison, the GWP produced in the whole supply chain for gasoline is $3884.5 \mathrm{~kg} \mathrm{ton}^{-1}$ of gasoline ( 1 ton gasoline $=43.5 \mathrm{GJ} \mathrm{LHV}, \mathrm{GWP}=89.3 \mathrm{~kg}-\mathrm{CO}_{2} \mathrm{GJ}^{-1}$ )
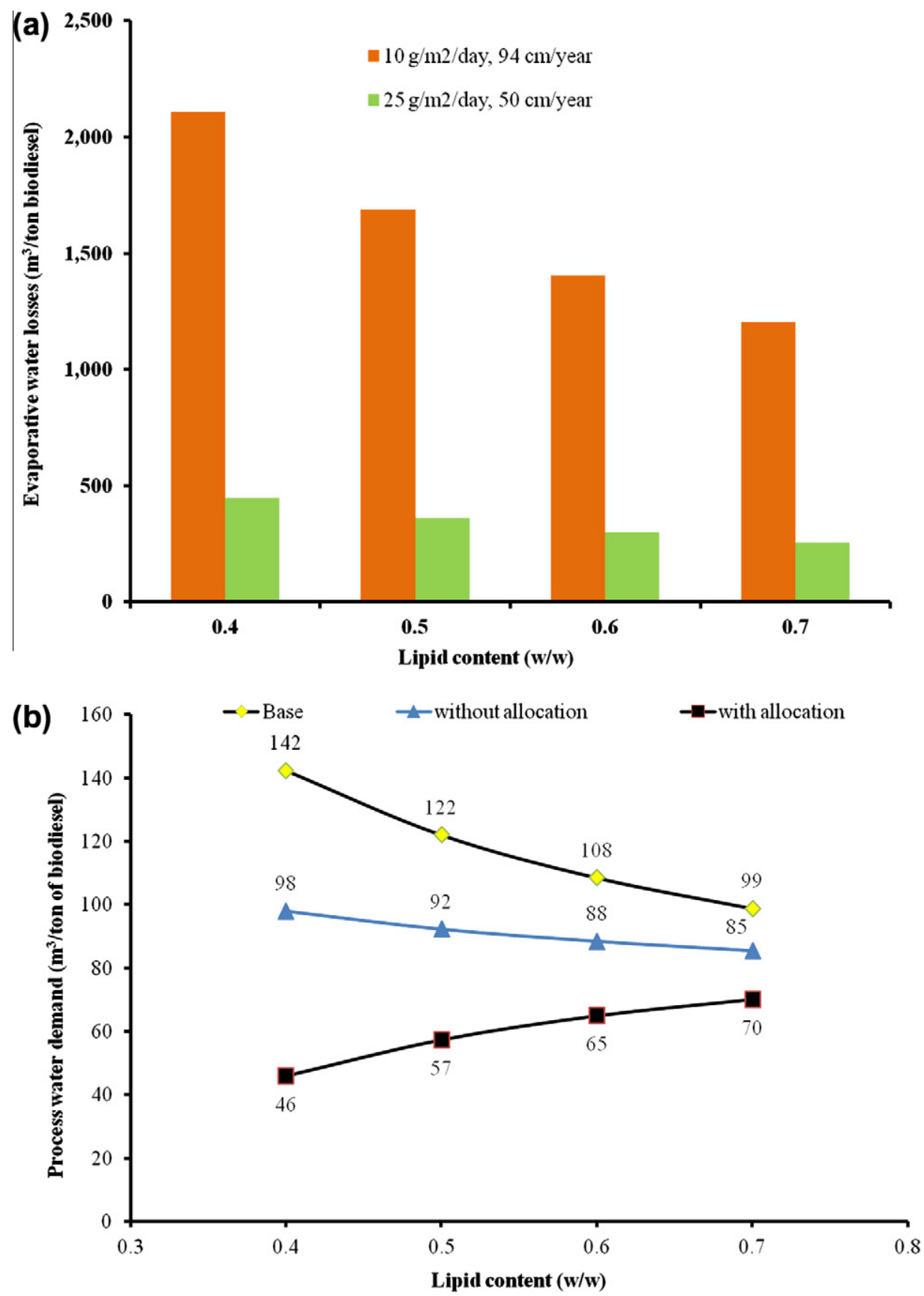

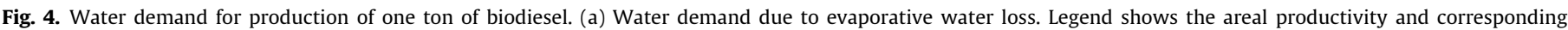

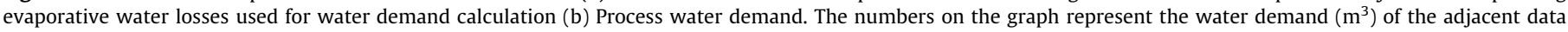
points. 
(Venkatesh et al., 2011). Hence, even in the highest GWP-generating scenario (no recycling and 0.4 lipid content), a $12 \%$ reduction in GWP is possible per GJ biodiesel consumption. In the integrated systems (with nutrient and energy recycle) a 43\% GWP reduction is achievable (per GJ biodiesel consumption). With recycle as well as allocation credits, a maximum GWP reduction of nearly $71 \%$ relative to fossil fuel can be obtained. GWP estimated in this study for the integrated process $\left(836-1790 \mathrm{~kg} \mathrm{CO}_{2}\right.$ ton $^{-1}$ of biodiesel produced without combustion) is comparable with other reported values of $700-1050 \mathrm{~kg}-\mathrm{CO}_{2}$ ton $^{-1}$ of biodiesel produced (Batan et al., 2010; Stephenson et al., 2010). In the present study, conservative values for LCA data were used (Supporting information Table S9). The electricity mix assumed here primarily consisted of coal-based power (70\%). However, use of energy sources with lower GWP per unit energy produced such as nuclear and wind would further reduce the GWP associated with the algal biofuel.

The system boundary in this study did not include GWP generated from land-applied residual biomass left after anaerobic digestion. Since residual biomass associated carbon is expected to be relatively recalcitrant with a degradation half-life much longer than biodiesel or biogas, it might be reasonable to assume that some fraction of this carbon is eventually sequestered into soil. With this assumption, the GWP of algal biodiesel can be further reduced. However, a portion of this residual carbon is also likely to degrade over time, but its life-cycle GWP is difficult to model due to complex reactions that could occur in the environment. Recently, it was estimated that $40 \%$ of the carbon in sludge remaining after anaerobic digestion of waste could be emitted as carbon dioxide after land application (Cayuela et al., 2010). However, positive outcomes, such as decrease in fertilizer demand or soil erosion as well as long-term improvement of soil aggregation properties and soil fertility, can also accrue from land application of the digested sludge. The GWP reductions due to these benefits and the increase in GWP due to digested sludge degradation are unknown.

\subsection{Water demand}

Evaporative water losses were the prevalent water demand driver compared to process water demand and varied with lipid content and biomass productivity. Fig. 4 a shows the evaporative water demand as a function of lipid content. For each lipid content, evaporative water losses were calculated at low $\left(10 \mathrm{~g}\right.$-algae $\left.\mathrm{m}^{-2} \mathrm{day}^{-1}\right)$ and high ( $25 \mathrm{~g}$-algae $\left.\mathrm{m}^{-2} \mathrm{day}^{-1}\right)$ biomass productivities. At the lowest biomass productivity and the highest evaporation rate, evaporative water losses were calculated to be as high as $2100 \mathrm{~m}^{3}$ ton $^{-1}$ of biodiesel produced (lipid content (w/w) of 0.4 ). Evaporative water losses can be lowered by one order magnitude if algal production rate was increased from $10 \mathrm{~g}$-algae $\mathrm{m}^{-2} \mathrm{day}^{-1}$ to $25 \mathrm{~g}$-algae $\mathrm{m}^{-2}$ day $^{-1}$ and evaporation rate was decreased from $94 \mathrm{~cm} \mathrm{yr}^{-1}$ to $50 \mathrm{~cm} \mathrm{yr}^{-1}$.

In addition to evaporative water loss calculations, process water demand was also estimated (Fig. 4b). The process water demand can be divided into three subcategories: (i) industrial water (i.e. water that was used for production of nutrient and electricity), (ii) water used for algal growth and biodiesel production (on-site use including fermentation and anaerobic digestion) and (iii) recycled water (Supporting information Fig. S3). During dewatering, $2 \mathrm{~g} \mathrm{~L}^{-1}$ algal suspensions were concentrated to $400 \mathrm{~g} \mathrm{~L}^{-1}$ algal slurry and thus around $99 \%$ water was recovered. The rest of the water was assumed to be lost during heat drying of algae and with anaerobic digester residues.

In the base case where nutrient recycling was not carried out, process water demand was the highest and ranged between 99 (for lipid content of 0.7 ) and 142 (for lipid content (w/w) of $0.4) \mathrm{m}^{3}$ ton-biodiesel ${ }^{-1}$ produced. In the integrated process, the process water demand without-allocation varies between 98 and
$85 \mathrm{~m}^{3}$ ton-biodiesel ${ }^{-1}$ produced. For the with-allocation scenario, the water demand is in the range of $46-70 \mathrm{~m}^{3}$ ton-biodiesel ${ }^{-1}$ produced. In the without-allocation scenario, an increase in lipid content from 0.4 to 0.7 decreased the water demand by $13 \mathrm{~m}^{3}$ tonbiodiesel $^{-1}$ produced. When allocation was taken into consideration, increase in lipid content increased the water demand by $24 \mathrm{~m}^{3}$ ton-biodiesel ${ }^{-1}$ produced (Fig. $4 \mathrm{~b}$ ). Due to nutrient recycling and energy production (biogas) in the without-allocation scenario, industrial water demand (and thus the total water demand) decreased due to less use of external energy and nutrient. When the allocation procedure was used, substitution of water demand for recycled nutrients and energy (biogas) further decreased the water demand. For the with-allocation scenario, an increase in lipid content increases the water demand since credits from substitution offset the process water demand created by the biofuel process.

For algal growth and biodiesel production steps, water demand was calculated to be within $4-8 \mathrm{~m}^{3}$ ton $^{-1}$ (direct consumption excluding evaporative losses) and is comparable with literature values (4.55 $\mathrm{m}^{3} \operatorname{ton}^{-1}$, Baliga and Powers, 2010). However the calculated process water demand presented here is lower than other reported values of 32-91 $\mathrm{m}^{3}$ ton-biodiesel ${ }^{-1}$ (Batan et al., 2010; Harto et al., 2010). Major part of the water that was recovered during dewatering (1200-700 $\mathrm{m}^{3}$ ton-biodiesel $\left.{ }^{-1}\right)$ was recycled in this study (Figs. S3 and S4, Supporting information). If water recycling was reduced by $4-5 \%$, net water demand would increase by $40-$ $60 \mathrm{~m}^{3}$.

For oil seed-based biodiesel, water demand estimates are reported to be between 18 and $409 \mathrm{~m}^{3}$ ton-biofuel ${ }^{-1}$. For other crop-based biofuels, water demand has been estimated to vary from as low as $3.7 \mathrm{~m}^{3}$ to as high as $1900 \mathrm{~m}^{3}$ (Dominguez-Faus et al., 2009; Harto et al., 2010). Although high, water footprint of algae based biodiesel can be lowered significantly by increasing productivity.

\section{Conclusions}

This study demonstrates that an integrated nutrient recycling and microalgae-based biodiesel production can achieve up to $71 \%$ reduction in the life-cycle greenhouse gas emissions compared to petroleum fuel. The net energy ratio of the integrated facility is also improved due to process integration relative to stand alone algal biodiesel processes. The water demand of algal biodiesel production, although high, can be lowered through improvement in biomass and lipid productivity. With appropriate process designs, microalgal biofuels have the potential to be simultaneously economically viable and environmentally sustainable.

\section{Appendix A. Supplementary data}

Supplementary data associated with this article can be found, in the online version, at doi:10.1016/j.biortech.2011.12.099.

\section{References}

Baliga, R., Powers, S.E., 2010. Sustainable algae biodiesel production in cold climates. International Journal of Chemical Engineering, 2010, Article ID $102179,13 \mathrm{p}$.

Batan, L., Quinn, J., Willson, B., Bradley, T., 2010. Net energy and greenhouse gas emission evaluation of biodiesel derived from microalgae. Environmental Science and Technology 44, 7975-7980.

Brentner, L.B., Eckelman, M.J., Zimmerman, J.B., 2011. Combinatorial life cycle assessment to inform process design of industrial production of algal biodiesel Environmental Science and Technology 45, 7060-7067.

Briand, X., Morand, P., 1997. Anaerobic digestion of Ulva sp. 1. Relationship between Ulva composition and methanisation. Journal of Applied Phycology 9, 511-524.

Bruhn, A., Dahl, J., Nielsen, H.B., Nikolaisen, L., Rasmussen, M.B., Markager, S. Olesen, B., Arias, C., Jensen, P.D., 2011. Bioenergy potential of Ulva lactuca: Biomass yield, methane production and combustion. Bioresource Technology 102, 2595-2604. 
Cayuela, M., Oenema, O., Kuikman, P., Bakker, R., Van Groenigen, J., 2010. Bioenergy by products as soil amendments? Implications for carbon sequestration and greenhouse gas emissions. GCB Bioenergy 2, 201-213.

Chisti, Y., 2007. Biodiesel from microalgae. Biotechnology Advances 25, 294-306.

Chowdhury, R., Apul, D., Fry, T., 2010. A life cycle based environmental impacts assessment of construction materials used in road construction. Resources, Conservation and Recycling 54, 250-255.

Clarens, A.F., Nassau, H., Resurreccion, E.P., White, M.A., Colosi, L.M., 2011. Environmental impacts of algae-derived biodiesel and bioelectricity for transportation. Environmental Science and Technology 45, 7554-7560.

Clarens, A.F., Resurreccion, E.P., White, M.A., Colosi, L.M., 2010. Environmental life cycle comparison of algae to other bioenergy feedstocks. Environmental Science and Technology 44, 1813-1819.

Collet, P., Hélias, A., Lardon, L., Ras, M., Goy, R.A., Steyer, J.P., 2010. Life-cycle assessment of microalgae culture coupled to biogas production. Bioresource Technology 102, 207-214.

Cordell, D., Drangert, J.O., White, S., 2009. The story of phosphorus: global food security and food for thought. Global Environmental Change 19, 292-305.

Coskun, C., Oktay, Z., Ilten, N., 2009. A new approach for simplifying the calculation of flue gas specific heat and specific exergy value depending on fuel composition. Energy 34, 1898-1902.

De Schamphelaire, L., Verstraete, W., 2009. Revival of the biological sunlight to biogas energy conversion system. Biotechnology and Bioengineering 103, 296304.

Dominguez-Faus, R., Powers, S.E., Burken, J.G., Alvarez, P.J., 2009. The water footprint of biofuels: a drink or drive issue? Environmental Science and Technology 43, 3005-3010.

Donner, S.D., Kucharik, C.J., 2008. Corn-based ethanol production compromises goal of reducing nitrogen export by the Mississippi River. Proceedings of the National Academy of Sciences 105, 4513.

EFMA, 2000. Production of N P K Fertilisers by the Mixed Acid Route. Best Available Techniques for Pollution Prevention and Control in the European Fertilizer Industry. Booklet No. 8 of 8 Best Available Techniques for Pollution Prevention and Control in the European Fertilizer Industry. European Fertilizer Manufacturers' Association, Brussels, Belgium.

Fischer, E., Porter, J., 1984. Anaerobic digestion of swine manure at various influent solids concentrations. Agricultural Wastes 11, 157-166.

Harto, C., Meyers, R., Williams, E., 2010. Life cycle water use of low-carbon transport fuels. Energy Policy 38, 4933-4944.

Kaufman, A.S., Meier, P.J., Sinistore, J.C., Reinemann, D.J., 2010. Applying life-cycle assessment to low carbon fuel standards - How allocation choices influence carbon intensity for renewable transportation fuels. Energy Policy 38, 52295241.

Kim, M., Ahn, Y.H., Speece, R., 2002. Comparative process stability and efficiency of anaerobic digestion; mesophilic vs. thermophilic. Water Research 36, 43694385.

Lardon, L., He lias, A., Sialve, B., Steyer, J.P., Bernard, O., 2009. Life-cycle assessment of biodiesel production from microalgae. Environmental Science and Technology 43, 6475-6481.

Mata, T.M., Martins, A.A., Caetano, N., 2010. Microalgae for biodiesel production and other applications: a review. Renewable and Sustainable Energy Reviews 14 217-232.

Murray, A., Horvath, A., Nelson, K.L., 2008. Hybrid life-cycle environmental and cost inventory of sewage sludge treatment and end-use scenarios: a case study from China. Environmental Science and Technology 42, 3163-3169.
Pokoo-Aikins, G., Nadim, A., El-Halwagi, M.M., Mahalec, V., 2010. Design and analysis of biodiesel production from algae grown through carbon sequestration. Clean Technologies and Environmental Policy 12, 239-254.

Redfield, A.C., 1958. The biological control of chemical factors in the environment. American Scientist 46, 205-221.

Redmond, K.T., 2007. Evaporation and the hydrologic budget of Crater Lake, Oregon. Hydrobiologia 574, 29-46.

Ruether, J., Ramezan, M., Grol, E., 2005. Life-Cycle Analysis of Greenhouse Gas Emissions for Hydrogen Fuel Production in the United States from LNG and Coal. National Energy Technology Laboratory, Pittsburgh, PA., Report \# DOE/ NETL-2006/1227.

Sander, K., Murthy, G.S., 2010. Life cycle analysis of algae biodiesel. International Journal of Life Cycle Assessment 15, 704-714.

Sarunac, N., Ness, M., Bullinger, C., 2007. One Year of Operating Experience with a Prototype Fluidized Bed Coal Dryer at Coal Creek Generating Station 3rd International Conference on Clean Coal Technologies for our Future. 3rd International Conference on Clean Coal Technologies for our Future. Cagliari, Sardinia, Italy, pp. 15-17.

Schenk, P.M., Thomas-Hall, S.R., Stephens, E., Marx, U.C., Mussgnug, J.H., Posten, C. Kruse, O., Hankamer, B., 2008. Second generation biofuels: high-efficiency microalgae for biodiesel production. Bioenergy Research 1, 20-43.

Spath, P., Mann, M., 2000. Life Cycle Assessment of a Natural Gas Combined Cycle Power Generation System. National Renewable Energy Lab., Golden, CO (US). Report no NREL/TP-570-27715.

Stephenson, A.L., Kazamia, E., Dennis, J.S., Howe, C.J., Scott, S.A., Smith, A.G., 2010. Life-Cycle Assessment of Potential Algal Biodiesel Production in the United Kingdom: A Comparison of Raceways and Air-Lift Tubular Bioreactors. Energy and Fuels 24, 4062-4077.

Uduman, N., Qi, Y., Danquah, M.K., Forde, G.M., Hoadley, A., 2010. Dewatering of microalgal cultures: A major bottleneck to algae-based fuels. Journal of Renewable and Sustainable Energy 2, 012701.

USEPA, 1985. Handbook: Estimating Sludge Management Costs. EPA/625/6-85/010.

Van Gerpen, J., Shanks, B., Pruszko, R., Clements, D., Knothe, G., 2004. Biodiesel production technology. Report for the National Renewable Energy Laboratory. Department of Energy, USA, pp. 30-42.

Venkatesh, A., Jaramillo, P., Griffin, W.M., Matthews, H.S., 2011. Uncertainty analysis of life cycle greenhouse gas emissions from petroleum-based fuels and impacts on low carbon fuel policies. Environmental Science and Technology 45, 125131.

Wijffels, R.H., Barbosa, M.J., 2010. An outlook on microalgal biofuels. Science 329, 796-799.

Xu, L., Brilman, D.W.F., Withag, J.A.M., Brem, G., Kersten, S., 2011. Assessment of a dry and a wet route for the production of biofuels from microalgae: energy balance analysis. Bioresource Technology 102, 5113-5122.

Yang, J., Xu, M., Zhang, X., Hu, Q., Sommerfeld, M., Chen, Y., 2011. Life cycle analysis on biodiesel production from microalgae: water footprint and nutrients balance. Bioresource Technology 102, 159-165.

Yazdani, S.S., Gonzalez, R., 2007. Anaerobic fermentation of glycerol: a path to economic viability for the biofuels industry. Current Opinion in Biotechnology $18,213-219$.

Yokochi, T., Honda, D., Higashihara, T., Nakahara, T., 1998. Optimization of docosahexaenoic acid production by Schizochytrium limacinum SR21. Applied Microbiology and Biotechnology 49, 72-76. 